\title{
Phillipson's Linguistic Imperialism Revisited at the light of Latin American Decoloniality Approach
}

\author{
Relectura de la obra de R. Phillipson: Imperialismo lingüístico, a la luz del enfoque \\ Iatinoamericano de la Decolonialidad
}

\section{Releitura da obra de R. Phillipson: o imperialismo linguístico, à luz da abordagem latino-americana da descolonialidade}

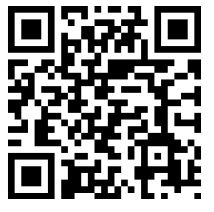

\section{Luis Guillermo Barrantes-Montero' \\ Universidad Nacional \\ Heredia, Costa Rica \\ luisba66@yahoo.es}

http://orcid.org/0000-0003-1633-8682

Recibido • Received • Recebido: 04 / 04 / 2016

Corregido • Revised • Revisado: 20 / 07 / 2017

Aceptado • Accepted • Aprovado: 07/ 09 / 2017

\begin{abstract}
A summary of the book Linguistic Imperialism, by Phillipson (1992) ${ }^{2}$ is presented here. The purpose is to highlight its current scope and permanent values in consonance with intuitions, criticism and alternatives proposed by Latin America Modernity/coloniality Group. Criteria of analysis are based on a re-reading of the work in the light of the decolonial perspective, with the aim of proposing pedagogical insights which guide language and literature teachers in approaching their study contents with a critical vision. The idea is to remark the role of English Language Teaching for the maintenance of power structures and for its potential for creating new epistemological approaches to language teaching and learning. An epistemological turnaround in the linguistic formation of future educational personnel is a must for that end.
\end{abstract}

Keywords: Linguistic imperialism; education, coloniality; de-coloniality; critical thinking.

\footnotetext{
${ }^{1}$ Posee una maestría Profesional en la Enseñanza del Inglés por la Universidad de Costa Rica (2006). Cuenta además con una licenciatura en Traducción Inglés-Español por la Universidad Nacional, Costa Rica (1996), una licenciatura en Teología por la Universidad Francisco Marroquín, Guatemala (1992) y un bachillerato en Filosofía por la Universidad Francisco Marroquín, Guatemala (1989). Durante diecinueve años se ha desempeñado como docente de inglés y de español como segunda lengua y actualmente coordina el Departamento de Cursos de Servicio en la Universidad Nacional, Costa Rica. Ha realizado ponencias en congresos internacionales y varios de sus artículos y ponencias han sido publicados en revistas como EDUCARE y LETRAS, ambas de la Universidad Nacional.
}

${ }^{2}$ First Published in 1992. Here is used the sixth impression from 2003. 
doi: http://dx.doi.org/10.15359/ree.22-1.1

URL: http://www.una.ac.cr/educare

CORREO: educare@una.cr

Resumen: Se presenta aquí una recapitulación de la obra Linguistic Imperialism [Imperialismo lingüístico] de Phillipson $(1992)^{3}$ con la finalidad de destacar sus alcances y valores permanentes en consonancia con las intuiciones, críticas y alternativas que propone el grupo latinoamericano modernidad/colonialidad. El criterio de análisis se basa en una relectura de la obra a la luz de la perspectiva decolonial, con la finalidad de proponer planteamientos pedagógicos que orienten a los profesores de lengua y literatura en el abordaje de los contenidos de estudio con una visión crítica. Concretamente, se trata de destacar el papel que la enseñanza de lenguas juega tanto a favor del mantenimiento de las estructuras de poder como su potencial para gestar aproximaciones epistemológicas alternativas. Se concluye que la formación lingüística del personal de educación requiere de un giro epistemológico para alcanzar ese fin.

Palabras claves: Imperialismo lingüístico; educación; colonialidad; de-colonialidad; pensamiento crítico.

Resumo: Este trabalho apresenta uma recapitulação da obra Linguistic Imperialism [imperialismo lingüístico] de Phillipson (1992) ${ }^{4}$, a fim de destacar o seu alcance e os valores permanentes de acordo com as ideias, críticas e alternativas propostas pelo grupo modernidade / colonialidade latinoamericano. A fundamentação para o critério de análises é baseada em uma releitura da obra à luz da perspectiva descolonial, a fim de propor abordagens pedagógicas que orientem os professores de língua e literatura. Dentro de este enfoque, a proposta é unir ao conteúdo do estudo uma visão crítica. Especificamente, este trabalho quer realçar o papel que o ensino de línguas desempenha, tanto para a promoção das estruturas de poder como também enfatizar seu potencial relacionado as abordagens epistemológicas alternativas. Em conclusão, a formação linguística dos profissionais da educação requer uma mudança epistemológica para alcançar esse fim.

Palavras-chave: O imperialismo lingüístico; educação; colonialidade; de-Colonialidade; pensamento critico.

\section{Introduction}

But to return to my new companion: - I was greatly delighted with him, and made it my business to teach him everything that was proper to make him useful, handy, and helpful; but especially to make him speak, and understand me when I spoke: and he was the aptest scholar that ever was.

-(Robinson Crusoe, by Defoe, 1965, p. 230)

Current teacher formation and, as a result, current English Language Teaching (ELT) take for granted the abilities forming personnel has to synthetize all dimensions of human life and devote all time and resources to implement a sort of curricula that entails basically an approach to language

\footnotetext{
${ }^{3}$ Publicado por primera vez en 1992. Aquí se consultó la 6 ta reimpresión del 2003.

${ }^{4}$ Primeira publicação em 1992. Aqui foi feita a consulta da 6a reimpressão de 2003.
}

2 Luis Guillermo Barrantes-Montero

Los artículos de la Revista Electrónica Educare del Centro de Investigación y Docencia en Educación de la Universidad Nacional, Costa Rica, se comparten bajo términos de la Licencia Creative Commons: Reconocimiento, № Comercial, Sin Obra Derivada 3.0 Costa Rica. Las autorizaciones adicionales a las aquí delimitadas se pueden obtener en el correo: educare@una.cr 
acquisition based on accuracy and communicative skills. Critical thinking does exist but hardly ever goes beyond discussing particular behavioral patterns in different cultures or confronting beliefs and values, but always taking for granted a system, a world order that is unquestionable.

Radical alternative ways of thinking are absent from that teacher preparation basically for two reasons. One is that formal education is supported and financed by both domestic and international structures of power with a clear interest in maintaining the educational system as an instrument of keeping control of production means and dynamics. The other is the unfortunately fragmented production of real critical thinking and alternative approaches within the very Higher Education institutions.

People in the so-called Third World countries usually complain for the disadvantages they have compared to those people in "developed, industrialized" countries. However, the power of language and the power of language teaching and learning in keeping those differences or overcoming them has been underestimated even for professionals in related fields as linguistics and applied linguistics. On the one side, linguistic phenomenon, at list by many scholars, seems to be studied per se as with little connection to real social, political implications of its structure and logic. On the other, applied linguists develop approaches to language teaching and learning for responding to immediate needs of the market, that is, for preparing workers for the production system, not for preparing people for whom the acquisition of a new language adds richness to their life project.

Imperialism, coloniality of power and alternative epistemologies are not common issues to be included in teaching textbooks or the ELT classroom. Nevertheless, there is a need for those topics to be included. Common people have the feeling that things need to change somehow, although they do not know the means through which it will be possible. Phillipson (1992) produced the work titled Linguistic Imperialism, in order to give an idea of the impact the diffusion of that language has had around the world as an instrument of colonialism by the British Empire and then, by the United States. In Latin America, the Modernity/Coloniality group, gathered three decades ago with the aim of studying the colonial matrix of power and depict alternative worlds to that imposed by modernity and lately by globalization. Members of this group are still working independently, on the same topics, though.

This paper is intended to connect the main insights in Linguistic Imperialism with the most relevant views and principles of coloniality/de-coloniality approach. The aim of this is to provide language and literature teachers as well as educators with some tools to approach their study contents with a critical view. By linking Phillipson's (1992) insights with an epistemological discussion of the real context where a foreign language is taught, a synchronic -and not only diachronic- perspective of language teaching is expected. 
doi: http://dx.doi.org/10.15359/ree.22-1.1

URL: http://www.una.ac.cr/educare

CORREO: educare@una.cr

For the purpose of this work, only some ideas of the most relevant representatives of the group will be brought to discussion in order to enlighten and provide with a new air what Phillipson (1992) wrote back in the early nineties. The idea is, precisely, to highlight the relevance that Phillipson's (1992) work still has for understanding the dynamics of power and the role English language and English language teaching has, on the one hand, in the maintenance and reproduction of those unequal relations of power between the North and the South, and, on the other hand, in the potential it has for creating new perspectives and alternative approaches to language and language teaching so that those relations can be modified for a respectful, inclusive and dignifying conviviality of people in both hemispheres.

It is important to mention that other works related to the topic have been produced more recently and address some of the topics approached by Phillipson (1992) too. Language in Late Capitalism, by Duchêne and Heller (2014) and Neoliberalism and Applied Linguistics, by Block, Gray and Holborow (2013).

Linguistic Imperialism is a book by Phillipson (1992). The author is a lecturer in English and language pedagogy at Roskilde University Centre in Denmark. The work was first published by Oxford University Press in 1992.

Phillipson (1992) provides readers with a first glance of his work by stating that it is aimed to explore the means by which the contemporary phenomenon of English has become so dominant. More exactly, in a first stage the book deals with historical issues in order to determine the extent to which the language has been promoted as an instrument of foreign policy by hegemonic English speaking countries. Secondly, language policies inherited by Third World countries from colonial times are analyzed so that the real scope of "aid" as support for educational development can be displayed and the intention of perpetuating the state of inequalities between North and South can be clearly identified. Thirdly, the ideology transmitted with, in and through English language Teaching (ELT) is regarded, attending to the role of language specialists and cultural export of English for that end.

One of the most intriguing questions the author poses at the beginning of his work is how the micro-level of ELT can be related to the macro-level of global inequality. One clue he offers for responding to it is the fact that the scientific study of language learning and language teaching, has been isolated from social sciences for too long, and ELT needs to be situated in a macro-societal theoretical perspective. Therefore, his theoretical approach is influenced by his experience of working with Tove Skutnabb-Kangas, thanks to which he has been able to integrate the perspective of those dominated (female, immigrant, mother tongue a "small" language) and the dominant (male, dominant group, mother tongue an "expansionist" language). The idea with that theoretically-based understanding of each perspective is to promote more justice for both groups (p. 3). 
Considered as a "world commodity", ELT demands a serious analysis since it is showing more characteristics of an industry than of a profession. In this sense, the power of English and the power of ELT around the world has to be put under discussion. For example, the successful promotion of English throughout the world, has been prompted by the global linguistic marketplace, in which the fashion of linguistic borrowing plays a main role. Certainly, it is undeniable the dominant position of English in science, technology, medicine and many other fields and, for that reason, neologisms and word borrowing tend to be common these days. Nevertheless, excessive use of those linguistic resources is putting in risk essential cultural and linguistic values of societies worldwide.

Phillipson (1992) considers that, while English was imposed by force in colonial times, contemporary language policies are determined by the state of the market ("demand") and the force of argument (rational planning in the light of available "facts", since English is equated around the world with progress and prosperity.) However, the truth is that in Third World countries, the wealth that English provides access to is very inequitably distributed. And no matter how "aid" to those countries increase, the gap between them and the rich North rather widens. Behind this dialectic lies an ethno-centrist approach to human relations.

In chapter two, Phillipson (1992) uses the metaphor of center-periphery (this concept was a contribution of Dependence Theory, developed by Latin American social scientists in the middle of the twentieth century), to contrast core English-speaking countries and periphery-English countries. In this regard, the clear tendency of the first ones is to advocate for a monolingualism, against bilingualism and multilingualism. Phillipson (1992) remarks the idea of monolingualism as having a "long pedigree" (p.19), since ancient Greek stigmatized as "barbarians" speakers of other languages. Today, monolingualism is claimed to be the condition for modernization, while multiplicity of languages is rather a nuisance. In the view of Phillipson (1992), English needs to be seen as one language in a multilingual framework both internationally and within core-English speaking country. However, Anglo-American monolingualism is rather impacting them negatively. This center-periphery dialectic is the source of all kinds of abuse like discrimination to immigrants, racism, the English-only standard, forcing people to language and culture assimilation. Actually, it is a matter of power and control, whose dynamics put English teachers in a central position for disseminating this "logic" under the premise and promise of modernization that peripheral countries require and "deserve".

Theoretical foundations for linguistic imperialism is treated in chapter three. A cautionary discussion about terminology takes place in this chapter. Terms like "tribe and dialect", "vernacular", "lingua franca", "underdevelopment", "modernization" and "Third World", among others, are all terms that include an ideological load favoring hegemonic countries and establishing a set of assumptions to see peripheral societies always in a position of inferiority. 
doi: http://dx.doi.org/10.15359/ree.22-1.1

URL: http://www.una.ac.cr/educare

CORREO: educare@una.cr

In addition, the term "linguicism", of which "linguistic imperialism" is a sub-type, is defined here and given special treatment. Linguicism is defined as "ideologies, structures and practices which are used to legitimate, effectuate and reproduce an unequal division of power and resources (both material and immaterial) between groups which are defined on the basis of language", while English linguistic imperialism is that "the dominance of English is asserted and maintained by the establishment and continuous reconstitution of structural and cultural inequalities between English and other languages" Phillipson (1992, p. 47).

Chapter 4 is about earlier work relevant to linguistic imperialism. Fishman (1972) as cited by Phillipson (1992) who analyses the choice of a national language or national languages in periphery countries, especially former British colonies. Here, the modernization-oriented elites justify the use of English (former colonial language) as a way to retain aid and keep trained personnel in order to meet the immediate operational demands of nationhood.

Another topic discussed in this chapter is language planning. Again, tendencies established by the market actually rule the favoring of English rather than other languages, even in large peripheral countries, like India.

One segment of this chapter is devoted to linguistic human rights. In this case, international covenants are claimed to establish sets of rules intended to make justice to languages in dominated. Nevertheless, these covenants have the weakness of being vague and too general and fail to help people in asserting their rights to maintain their local languages alive.

Chapter 5 refers to the Colonial linguistic inheritance Phillipson (1992) quotes Defoe (1965). Those appealing words are used there to introduce the topic of the essential role of proficiency in English for functioning properly in colonial and peripheral countries. Educational policies have been designed from core-English nations to serve their interests, among which was the establishment of educated local elites who function as interpreters in the first stages of the settlements. However, in the following times, native speakers have been required for decision making positions at all levels.

Chapter 6: This chapter deals with the ways Britain and United States have promoted English worldwide. After World War II, both the United Kingdom and the United States started campaigns of promotion of their languages in peripheral world. On one side, the British Council is presented as an instrument of propaganda with a façade of autonomy. On the other side, The United States created several organizations to promote English and, more than that, replace Britain as the center of English language diffusion.

A crucial topic discussed in this chapter is that of the role of ESL profession in promoting U.S. major interests. In the context of war and post war, American ESL and Applied Linguistics were dominated by linguists rather than by educationalists. Structuralism was at the time the 
leading trend in linguistics and behaviorist was its psychological counterpart. From there, teaching methodology was transferred uncritically not only for the teaching of English abroad, but for the teaching of languages to military personnel.

In chapter 7, the professional base on which ELT expanded is presented. In the view of the architects of that professional base, the whole world was their laboratory. In accordance with other forms of imperialism (economic, politic and military), scientific and educational imperialism ensured the accumulation of expertise and theory building in the Center. Ideas are extracted from periphery just like raw materials are extracted from there too (with peripheral scholars cooperate with this system).

Following the Macawlay doctrine (or macawlayism), the author says, the educational language planning for underdeveloped countries has included several tenets regarding the teaching of English. These tenets are included in Makerere Report (1961) and its "English-only" policy. The first one is that English is better taught monolingually; the second, the ideal of English teachers as a native speaker; the earlier the English is taught, the better the results; the more the English is taught, the better the results; if other languages are used much, standards of English will drop. All those tenets are demythologized as fallacies. Since, first of all, they show a severe ethnocentrism and lack evidence that support those assumptions.

ELT in action is the subject matter of chapter 8. Here, linguicism is said to have taken over from racism as a more subtle way of hierarchizing social groups in contemporary world. Unfortunately, Phillipson (1992) states that monolingually-oriented Europeans fail to recognize the linguistic richness of language varieties. Learners at all levels are presented only EuropeanAmerican perspective. In Kenyan experience, for example, Phillipson (1992) quotes Ngügi (1981) who affirms that, because of British imperialist literature "our students are daily being confronted with the European reflection of itself, the European image. Our children are made to look, analyze and evaluate the world as made and seen by Europeans" (p. 241).

In this state of things, the educated people in peripheral countries internalize the values and points of view of the Center countries until the point that the presence of native speakers is not necessary there, since the cooperation of these scholars plus the assistance offered by the computers ensures the control of the periphery by core-English countries.

Chapter 9 is about arguments in linguistic imperialism discourse. Three types of arguments in accordance with three types of power are presented by Phillipson (1992), making reference to Galtung (1980), in order to understand how English is promoted and sold.

The first type are intrinsic arguments. They are related to the capacities: What English is: A rich, varied and noble language, well adapted for change. The second type are extrinsic arguments. They are related to resources: What English has: Textbooks, dictionaries, grammar 
doi: http://dx.doi.org/10.15359/ree.22-1.1

URL: http://www.una.ac.cr/educare

CORREO: educare@una.cr

resources, trained teachers, etc. The third type are functional arguments. They are related to users. What English does: English provides access to modernization, science and technology. All these kinds of discourse are constitutive of the logic of power in language teaching and marketing.

Finally, chapter 10 deals with linguistic imperialism and ELT. In this chapter the author takes back the topic of linguicism. He points out that this is a neologism, a construct for understanding how language decisions produce inequalities. In this sense, linguicism is said to have taken over racism as an ideology for legitimating that unequal division of power and resources.

At the end, the author poses the following question: Can ELT contribute constructively to greater linguistic and social equality, and if so, how could a critical ELT be committed, theoretically and practically, to combating linguicism?

\section{The Latin American De-coloniality Approach}

Latin American Modernity/Coloniality Group (M/C Group) was an interdisciplinary network of critical thinking that started in the first decade of XXI century. This group, as Veronelli (2015) pointed out, included among others, sociologist Aníbal Quijano and Ramón Grosfoguel, Semiologist Walter Mignolo, anthropologists Arturo Escobar and Fernando Coronil, philosophers Enrique Dussel, Santiago Castro-Gómez, María Lugones and Nelson Maldonado Torres. Those thinkers created what they called the Modernity/Coloniality Project, which involved three wellarticulated concepts: Coloniality, Transmodernity and Border Thinking. A brief description of those concepts is presented as follows.

\section{Coloniality}

According to Maldonado-Torres (2007), coloniality has to be distinguished from colonialism, or colonial period. This one refers to a specific and formal relation of power among two societies during a given period of time. Coloniality, instead, is a pattern of power that emerged as a byproduct of modern colonialism, one which continues to exist once the colonial administration period has even disappeared. The concept of coloniality involves the way through which knowledge, work, authority and intersubjective relations are interwoven in the world-capitalist market and in the idea of race and its derivations. Therefore, coloniality is ever-since present in each aspect of everyday life experience of people in both, colonizing and colonized societies: in the collective imaginary, in individual beliefs and expectations, in academic production and teaching manuals, in common sense, and in many other dimensions of their life.

The origin of coloniality roots back to the discovery and conquest of the Americas in the sixteenth century. However, for Quijano and Wallerstein (1992) that concept of "the Americas" should be understood as a geo-social construct created in the sixteenth century upon which the 
modern world system was born. The New World was the "badge and burden" through which the Americas were recognized from outside. The authors named "Americanity" the whole system created around the construct of "the Americas" and "New World". Such a pattern included four elements: Coloniality, ethnicity, racism and the concept of newness itself.

The first element, coloniality was in the beginning (sixteenth and seventeenth centuries) a set of colonial states within an interstate system (Viceroyalties) in hierarchical layers in all domains: cultural, economic and political. Eventually, the independence movements, inspired by nationalism, created the state-nations we know today. Nevertheless, independence did not suppress coloniality, it only changed the administrative forms. The second element, ethnicity, is a set of communal boundaries put for locating and ranking people within a state. Ethnicity was essential for marking the boundaries in the division of labor system. However, ethnicity boundaries were far from enough for maintaining the new-world structures. Obviously already implied in ethnicity, racism, the third element, was reinforced and articulated, especially after the slavery abolition in North America. This formal segregation has had varied forms and consequences, among which, one must be remarked: In the second half of the twentieth century, during the Cold War, when the United States became leader of the New World, racist criteria ruled immigration policies and the concept of "Third World Within" was born to refer to people from non-European countries aiming to enter the U.S.

Following Quijano and Wallerstein (1992), the fourth element, "newness" requires a special treatment. It refers to the faith in science, which is the pillar of modernity. Untied from old and traditional links, modernity became a synonym and proof of success. Under the "newness" element, whatever was new, was supposed to be better, and the western culture, initially represented by Britain, and then replaced by the United States, have been the leaders of newness. But, this apparently only positive appraisal of modernity hides a "dark and hidden side": coloniality. The excitement produced by newness, consciously in some people and unconsciously in others, diverted their attention from realities like the gap between central and peripheral societies, development and underdevelopment, social inequalities and the creation of new barriers, built to reinforce the difference between them.

According to Mignolo (2001), modernity is also a construct, a European narrative that absolutely requires coloniality for making sense. A colonial matrix of power is at the very foundation of inequalities, exploitation, segregation, racism, and all other forms of marking differences among human beings. This has been so since the first manifestations of modernity, in Renaissance, with the proclaiming of "the power of reason" over the former power of myths and traditions of the Middle Age to the globalized, polycentric capitalist world of today.

Modernity has shown three accumulative, although not consecutive faces along the centuries. First one is the Catholic-Iberian one, leaded by Spain and Portugal, from 1500 to 1750; 
doi: http://dx.doi.org/10.15359/ree.22-1.1

URL: http://www.una.ac.cr/educare

CORREO: educare@una.cr

the second one is the face of the "hearth of Europe" (as named by Hegel), leaded by England, France and Germany, from 1750 to 1945; and the third one is the North American face, leaded by the United States from 1945 to the year 2000. Since then the globalized, polycentric world has been interconnected within the same type of economy.

Throughout those historical periods, coloniality, as viewed by Maldonado-Torres (2007) has established forms of subordination for controlling economic and social relations. Such forms are articulated in two axes: First is the axis of codification of the difference between conqueror and conquered, by means of a pretended biological structure of domination named "race"; second, the structure created for controlling labor and resources in the existing means of production. What makes coloniality easy to be transmitted through generations is that those forms of power and division have penetrated the collective imaginary. In a subtle way, even when officially all people are "equal" to the law, former European experience of the "reason" defeating "barbarians" is maintained in coloniality in relations of superiority - inferiority, in which European, white, Christian, male, are in position of superior, and therefore, more human; while those who do not fit those standards are inferior, and therefore, less human.

Such biased way of thinking has also been taken to science thinking and research. In that way, many scholars and researchers have taken for granted those dualisms, and it is not unusual to find books and others sources that include the concept of race and its sub-divisions. This is, according to Maldonado-Torres (2007) a Manichean, misanthropic dualism which, based on the "line" of color, establishes standards for rating people as more or less discardable in the production - consumption system.

Either we like it or not, coloniality is present today in teachers and other stakeholders in education. Therefore, if nothing is done about it, this structure of domination and supremacy will continue to be assimilated by new generations forever. Nevertheless, there are powerful reasons to think that education can make a difference. In that sense, Walsh (2007) states the following: Thinking of a de-colonial turning or overturn regarding knowledge and education implies taking seriously not only the contributions, but also the repercussions of neglected, marginalized and subalternalized local histories and epistemologies... But maybe, even more important, political as well as ethical attention to our own practices and places of enunciation... In order to confront the hegemony and coloniality of western thinking it is also necessary to face and make visible our own subjectivities and practices, including our pedagogical practices.

The European reflection of its own modern history has produced discourses like Martin Heidegger's ontology. He departs from the idea of the human beings, taking for granted he is referring to the European, who exists in the world as the man who-is-there, "thrown to existence". For him, the collective "Dasein" finds its principle of individuality in death. However, the experience of those with no power, who have been deprived of a real and dignified existence 
by the coloniality matrix of power, of being, and of knowledge, has produced reflection too. Fanon (1961) has named them the Damnés de la Terre, or the wretched of the Earth. For Fanon (1961), the Damné is the one who is-not-there, not in an ontological sense, but just because the hegemonic powers have made him invisible. The reflection of the Damné is re-writing the story, is thinking of alternative ways of establishing relations among humans. This is the principle of Transmodernity, developed by Dussel (2012) as follows:

\section{Transmodernity}

As several authors have pointed out, modernity has entered into crisis. This does not mean it is about to disappear; instead, it is being consolidated. However, this is an opportunity to make visible alternative ways of being that modernity has kept hidden for centuries Castro-Gómez (2000). In addition, the crisis of modernity, due to its own failing to recognize its dualist and exclusionist structure has created its own criticism: Postmodernity. According to Ponce (2011), authors like J. Habermas and others have criticized modernity in different forms. However, they offer a reflection of pitfalls and weaknesses of modernity from within. For Modernity - Coloniality Project authors, this criticism is not what is needed. A new way of thinking has emerged from the "exteriority", that is from the identity of those whose existence has been denied, neglected and ignored by modernity and its institutionalization of difference.

In his essay about Transmodernity and Interculturality, Dussel (2012) explains that he has introduced the term trans-modernity referring to a new form of cross-cultural dialogue. The idea is to establish conditions for dialogue between all those universal cultures which certainly keep important asymmetries among them. All those cultures have co-existed with European modernity and keep otherness with it. Those cultures can be called "pre-modern", since have existed since long before European modernity. They cannot be post-modern, though, because modernity has not included them. They are starting to be trans-modern, because they are being born again, and are creating bridges among them. Trans-modernity, then takes into account what had been denied by modernity.

This cultural trans-modernity does not aim a universality. As Dussell (2012) states: A future Trans-modern culture, which assumes the positive moments of Modernity (however evaluated with different criteria from other millenary cultures) will contain a rich pluri-versity and will be the result of an authentic intercultural dialogue, one which takes clearly into account the existing asymmetries.

The main error of European modernity was precisely its attempts to straighten itself as universal, as the top standard for everything. Trans-modernity aspirations are creating conditions for a multi-diversity, one world in which many worlds fit. 
doi: http://dx.doi.org/10.15359/ree.22-1.1

URL: http://www.una.ac.cr/educare

CORREO: educare@una.cr

In that sense views Dussel (1980) the role of Latin American pedagogy: Current Latin American pedagogical ontology is rooted in a long term European and North American history. In this case... we should rely on the culture of the 'center' in order to understand the origin of our own pedagogy. We will devote ourselves to discover the foundations, the root of the "mechanism" of cultural domination which, with little exceptions has plenty of operations in our continent.

Trans-modernity faces the challenges of modernity today, but "otherwise", with a different epistemology and from the outside of the Modernity. This is what is meant by border thinking.

\section{Border thinking}

In his work Epistemic Disobedience, Mignolo (2010) develops his ideas of border thinking. Of course, he has taken into account the insights of thinkers of M/C Group as well as other thinkers like Fanon (1961), and his approach of the coloniality of being from the racial experience, and Césaire (1955), with his proposal of a De-colonial turnaround.

Mignolo (2010) distinguishes between emancipation and liberation. To him, the first term was used to refer the movements that gave freedom to one social class, the bourgeoisie from their imperial dominators in Europe. That is not what people in trans-modernity need. Instead, liberation is more likely to catch the meaning of these people goals: Liberation departs from a radical detachment from coloniality episteme. People in the exteriority of modernity are not looking for alternative modernities, they want an alternative to modernity:

By means of getting awareness and because of the need to legitimate ways of (self) thinking devaluated by actors (and institutions) that control the principles of knowledge; by rising consciousness of living in the epistemological and ontological borders; and by inhabiting the exteriority, Border Epistemology emerges as a method for de-colonial thinking as well as for the routes of de-colonial options (Mignolo, 2010).

However that detachment is required in border epistemology, the influence of European modernity in other cultures is undeniable. Therefore, new conditions for dialogue should be established. In an interview with W. Mignolo, conducted by Iñigo and Sánchez-Mateos (2007) Mignolo stated that from the sixteenth century to the present, not only an economic and political expansion (of Europe) has taken place, but, essentially, an epistemic one. That is how terms like "humanitas" (enlightened European men) versus "anthropos" (barbarians), "primitive", "communist", "terrorist" and others have appeared. For example, "anthropos" is not the "outsider" of the "humanitas", but its exteriority. That means, it is not an ontological otherness, but a perception. Those who have given themselves the position of "humanitas" have put the others in the position of "anthropos", in order to create a difference that justifies the unequal relations we have referred to. 
Border thinking emerges from the acceptance to have been categorized as "anthropos" by the imperial/colonial, racist, ontological and epistemic violence. From there, the task for those in the exteriority is dwelling that exteriority; then, expressing themselves from there, reaffirming their points of view and promoting liberation not only for themselves but also for those who have based their epistemology and worldview on prejudice. Warning: They do not recognize themselves as "anthropos" or "barbarians", there are not ontological "anthropos" or "barbarians". Those terms are an invention of the categorical system that was created by western agents. In the same interview by Iñigo and Sánchez-Mateos (2007) Mignolo quotes Fausto Reinaga, a radical Aymara thinker who once said: Damn! I am not an Indian, I am Aymara. But I have been made an Indian, and, as such, I will fight .

\section{The Influence of Language in Coloniality and De-coloniality in present times}

For a better contextualization of the power of language in conquest and colonization of the New World it is recommended to see Mignolo (2005). This section is rather aimed to show how language power is used in present times for reproducing and keeping coloniality intact.

Veronelli (2015) has made an analysis of the relation between race and language from the perspective of Modernity/Coloniality-Decoloniality project. Basically, she has pointed out the linguistic and communicative consequences of racialization. First among these consequences is the monologic character of modernity that closes itself to the possibility to establish dialogues with other ways of thinking and living. By establishing exteriorities and considering non-center societies as inferior, modernity makes interlocution impossible. In such conditions, those in position of conquered or dominated are only able to follow the rules set by those in power. Language is used, then, only as a vehicle of giving and understanding rules, and behavior patterns that serve the interests of globalized modernity-inspired market.

Another relevant insight Veronelli (2015) presents is that "colonized/colonialized" people have developed communities of language among them. They have practiced languaging for sharing their common experiences from the perspective of powerless society and this is an instrument for them to struggle together. Against monolingualism, promoted by the rhetoric of modernity and the logic of coloniality (Mignolo, 2010), these people have developed not only the capacity to resist, but also the ability to create new ways of thinking, new epistemologies.

Certainly, in this poly-centric, globalized, capitalist world of today, fear is increasing as never before. That fear is being promoted, monitored and controlled by centers of power to benefit their interests. Ordóñez (2006) lists three factors that intervene in the phenomenon of collective fear: The propagation of new forms of terrorism, the pervasive presence of Mass Media in everyday life of people worldwide and the strategic used of fear by political, economic global powers. This third factor is close-related to the analysis of Phillipson (1992). One strategy is for sure the continuous dissemination and broadcasting of loaded words and terms intended to reinforce in 
doi: http://dx.doi.org/10.15359/ree.22-1.1

URL: http://www.una.ac.cr/educare

CORREO: educare@una.cr

the collective imaginary of people the "Manichean, misanthropic skepticism (Maldonado-Torres, 2007) that makes them to believe that "the other" is the enemy. Whatever difference among people is enough for establishing barriers among them. At the same time, those loaded words and terms in the form of subtle propaganda spread the false idea that keeping close and sharing the ideology of the centers of power is the safest way to live. Something like what Ramonet (1998) referred to in La Pensé Unique or The Single Thought.

In addition, in so-called "Third World", "developing" or "emerging" countries (all those loaded terms, as seen above), ELT continues to be sharing a frank structuralist approach. This contributes to an uncritical acquisition of the language, which definitely benefits the interests of power sectors. Phillipson (1992) criticized the structuralist-oriented applied linguistics, and the reasons for that criticism are apparent: no critical thinking is being developed in learners of English as a foreign language. A post-structuralist approach to linguistics proposes the power of performative speech to enhance the historicity of communicative acts. (Morales, 2014) considers that meaning is produced, established and questioned in particular contexts. Therefore, it is important to analyze the temporality of concepts and terms, in order to be aware of possible new meanings they have acquired in different times and places.

\section{An Attempt to Respond to a Question Posed in 1992}

Now it is time to recall, and try to propose an answer to the question posed by Phillipson (1992, p. 319) at the end of his book: "Can ELT contribute constructively to greater linguistic and social equality, and if so, how could a critical ELT be committed, theoretically and practically, to combating linguicism?"

As the question has two parts, the answer should be given in two parts, as well:

A) Doubtlessly, ELT has a great potential to contribute to linguistic and social equality. However, a paradigmatic and epistemological transformation of teacher preparation and teaching profession has to take place as a sine-qua non condition. In-service teachers and teacher trainers today have been taught and are still taught according to the paradigm of modernity. Actually, many of them are not even familiar with concepts like epistemological approaches or coloniality. This is because curriculum design for teaching careers and textbook choosing just take for granted that textbooks and materials offered in the market by main publishing houses is the "path to follow". Alternative approaches to ELT are unthinkable in most institutions. Not to mention that current boom of English learning in countries like Costa Rica, México and Colombia is triggered by the promise of warranty of jobs for young professionals. Public universities obtain financing from international institutions like WB and IMF, those which have clear and definite policies for approving their loans. 
In addition, ELT conferences in TESOL focus mainly on pedagogical, methodological and cultural issues. It is unusual to see presentations about epistemology of language teaching in such conference programs.

Why is this so? According to Mora (2014), education is, in fact, a cultural space for constructing meaning. In that field, financial multinational organizations (World Bank and IMF) started, back in the nineties, ambitious educational reforms which involved, not only loans for infrastructure but also an active participation in curricular policies, at every, but mostly at higher education level. That was aimed to form "human capital" and re-orient teacher formation to the requirements of the globalized market. As a result, curriculum has been used as a regulation instrument in order to control what is included in course design and implementation.

In addition, and following Mora (2014), curriculum is viewed as not neutral, that is, as a tool to promote -and impose- society models, as well as political, philosophical and cultural options. Moreover, this author points out the use of curriculum as the expression of a cultural and political project that promotes the models of society of supremacy groups.

All this is a brief summary of the presence of coloniality in curricula design and implementation in Latin America, and shows how the insights remarked by Phillipson (1992) have not become obsolete at all.

Mora (2014) also argues three very relevant points regarding teacher formation and curricular policies in Latin America. It is presented as follows.

1. A scholar-ethnocentric emphasis of the approaches, a non-Latin American epistemological matrix; and a functional, structuralistic view of teachers as knowledge transmitters.

2. A reduction of curricular production. This promotes a uni-disciplinary approach of curriculum objectives and contents, as well as evaluation practices that grade achievements and behaviors previously programmed and pretends to measure, by means of that, the formation process, as a whole.

3. "Subordination of the political frame of formation. This means to conceive the professionalization of teachers as preparing them for an instrumental knowledge, rather than an integral, pedagogic formation.

This reference to Mora (2014) has been very useful to present the theoretical and philosophical debate of coloniality in educational curriculum and how a change for an 
doi: http://dx.doi.org/10.15359/ree.22-1.1

URL: http://www.una.ac.cr/educare

CORREO: educare@una.cr

interdisciplinary and emancipatory approach needs to be born, if Latin American countries really want to somehow overcome the influence of coloniality.

A) The second part is not a yes/no question. It demands the means through which it could be achieved. Well, the key concept is given in the question: critical ELT. For ELT to be critical it is necessary that ELT theorists and practitioners who believe in alternative epistemologies should not only write books and articles for a very close circle of readers. They need to promote encounters with other fellow scholars involved in educational subjects and share those concerns. That is the only way to create conditions for alternative thinking and inter/transdisciplinary approaches in Higher Education.

LT staff in Higher Education level need to be honest to their learners and create awareness among them of the need they have to understand their career as part of a broader life project and not only as a training period to rush for a job. Certainly, people need to make their living and practical and utilitarian objectives are valid in the present world order. Once such awareness starts to be shared by professors and learners, a rationalization and real dimensions of linguicism can be discussed in the classroom and new insights can be elicited from forming professionals and ELT teachers. What is meant here is that an alternative worldview to that based on coloniality of power, being and knowledge is only possible by means of education. And education can only be effective in that way by means of an epistemological transformation.

As it can be seen, a clear connection between Linguistic Imperialism and Latin American De-coloniality Approach can be very helpful to promote and/or enhance critical thinking in language teaching. Phillipson (1992) remarks the idea of the power of language to impose the supremacy of a human group upon others. This is a main source of discrimination, segregation and all forms of hindering a healthy conviviality among people.

Likewise, De-coloniality perspective highlights exactly the same issues, although in a specific geo-referenced context: Latin America, and beyond: The Global South, that is, all regions of the world where western culture imposes its supremacy and exerts domination.

Based on this, when ELT teachers, as well as literature teachers, plan and develop courses, they can take into account that textbooks and all other materials they make use of in their lessons contain the worldview of their producers; one which, by no means necessarily coincides with that of the receivers. Therefore, a critical analysis must take place previously each lesson is taught. 


\section{Conclusions}

This paper has presented a brief account of the most relevant ideas in the book by Phillipson (1992) Linguistic Imperialism. In addition, main principles in de-coloniality Latin American theory have been described and discussed in order to find similarities or points of coincidence with the work by Phillipson (1992). In that sense, the different chapters of Linguistic Imperialism have been presented in their essential content. Likewise, Latin American De-colonial perspective was also addressed, although very briefly. At least, however, the concepts of coloniality and decoloniality have been presented. In addition, other relevant concepts in Latin American thought were included, that is the case of Transmodernity and Border Thinking. And, of course, main repercussions of coloniality and de-coloniality in present times were also addressed.

A central issue in this work has been the attempt to respond to the question posed by Phillipson (1992) at the end of his book. That question is about whether or not and the extent through which current ELT can contribute positively to a greater social and linguistic equality. The answer presented here is that such contribution does have a great potential. However, there is a sine qua non condition, which is the preparation of new generations of educators at every level in Higher Education. A paradigmatic revolution in epistemological foundations of future teaching, research and administrative staff needs to take place so that alternative worldviews can be attained.

The biggest challenge for those scholars committed with the future of education in terms of making a difference in overcoming the racial prejudice and the "Manichean misanthropic skepticism", has to do with the reinforcement of the means of fair human conviviality. This requires the promotion of encounters with professionals of different fields related to education. By means of an interdisciplinary approach to education, it is possible to bridge education and social justice. Language power and language use is a key stone in this changing impact.

Further research needs to be done in terms of finding ways to share that Latin American thought in broader spaces, so that more people can be identified with this approach. In that way, the idea of "Border Thinking" can be a reality as well as an enriching experience for everyone.

This paper has been inspired in Costa Rican national reality; however, it is expected to enlighten similar situations in other countries. Feedback and sharing experiences of what has been found or has been done to cope with these realities are welcome.

\section{References}

Block, D., Gray, J.,\& Holborow, M. (2013). Neoliberalism and applied linguistics. USA: Routledge.

Castro-Gómez, S. (2000). Ciencias sociales, violencia epistémica y el problema de la "invención del otro". En E. Lander (Comp.), La colonialidad del saber: Eurocentrismo y ciencias sociales. Perspectivas latinoamericanas (pp. 88-98). Buenos Aires: CLACSO. Recuperado de http:// bibliotecavirtual.clacso.org.ar/clacso/sur-sur/20100708034410/lander.pdf 
doi: http://dx.doi.org/10.15359/ree.22-1.1

URL: http://www.una.ac.cr/educare

CORREO: educare@una.cr

Césaire, A. (1955). Discourse on colonialism. New York: Monthly Review Press. Recuperado de: http://www.rlwclarke.net/Theory/SourcesPrimary/CesaireDiscourseonColonialism.pdf

Defoe, D. (1965). The life and adventures of Robinson Crusoe. London: Seeley, Service \& Co. Recuperado de: http://www.gutenberg.org/files/521/521-h/521-h.htm

Duchêne, A., \& Heller, M. (Eds). (2014). Language in late capitalism. Pride and Profit. New York: Routledge.

Dussel, E.D. (1980). Lapedagógica latinoamericana. Bogotá: Editorial Nueva América. Recuperado de http://www.habilidadesparaadolescentes.com/archivos/1980 La pedagogica Dussel.pdf

Dussel, E. D. (2012). Transmodernity and intercuturality: An interpretation from the perspective of philosophy of liberation. Transmodernity: Journal of Peripheral Cultural Production of the Luso-Hispanic World, 1(3), 27-59. Recuperado de: http://escholarship.org/uc/item/6591j76r

Fanon, F. (1961). The wretched of the earth. New York: Grove Press. Recuperado de http://abahlali. org/files/On Violence.pdf

Iñigo, M., \& Sánchez-Mateos, P. (2007). Sobre pensamiento fronterizo y representación. Entrevista a Walter Mignolo. Bilboquet, 8 Bárbard, 1-17. Recuperado de https://es.scribd. com/doc/36433296/Sobre-pensamiento-Fronterizo-y-Representacion-Entrevista-aWalter-Mignolo

Makerere Report. (1961). Report of the commonwealth on the conference on the teaching of English as a second language. Entebbe: Commonwealth Education Liaison Committee.

Maldonado-Torres, N. (2007). On the coloniality of being: Contributions to the development of a concept. Cultural Studies, 21(2-3), 240-270. doi: 10.1080/09502380601162548

Mignolo, W. D. (2001). La colonialidad: La cara oculta de la modernidad. Cosmópolis: el trasfondo de la Modernidad. Barcelona: Península. Recuperado de http://www.macba.es/PDFs/ walter mignolo modernologies cas.pdf

Mignolo, W. D. (2005). The idea of Latin America. USA: Blackwell Publishing.

Mignolo,W.D. (2010).Desobedienciaepistémica: Retórica delamodernidad, lógica dela colonialidad y gramática de la descolonialidad. Buenos Aires: Ediciones del signo. Recuperado de https://antropologiadeoutraforma.files.wordpress.com/2013/04/mignolo-walterdesobediencia-epistc3a9mica-buenos-aires-ediciones-del-signo-2010.pdf 
Mora, A. (2014). La construcción cultural del currículo: Reflexiones en clave latinoamericana. Revista Ensayos Pedagógicos, 9(2) 17-47 Recuperado de: http://www.revistas.una.ac.cr/ index.php/ensayospedagogicos/article/view/7297/7545

Morales, M. V. (2014). Discurso, performatividad y emergencia del sujeto: Un abordaje desde el post-estructuralismo. Athenea Digital, 14(1), 333-354. Recuperado de https://ddd.uab.cat/ pub/athdig/athdig a2014m3v14n1/athdig a2014m3v14n1p333.pdf

Ordóñez, L. (2006). La globalización del miedo. Revista de Estudios Sociales, 25, 95-103. Recuperado de http://www.redalyc.org/pdf/815/81502512.pdf

Phillipson, R. (1992). Linguistic imperialism. Oxford: Oxford University Press.

Ponce, M. F. (2011). La modernidad como objeto de indagación filosófica en Jürgen Habermas. $A$ Parte Rei. Revista de Filosofía, 73, 1-9. Recuperado de http://serbal.pntic.mec.es/AParteRei/ ponce73.pdf

Quijano, A., \&Wallerstein, I. (1992). Americanity as a concept, or the Americas in the modern world-system. ISSJ, 44(4)134, 549-557. Recuperado de: http://www.javeriana.edu.co/ blogs/syie/files/Quijano-and-Wallerstein-Americanity-as-a-Concept.pdf

Ramonet, I. (1998). Geopolitics of chaos. Internationalization, cyberculture \& political chaos (Translated A. Lyn Secara). Nueva York: Algora Publishing.

Veronelli, G. A. (2015). The coloniality of language: Race, expressivity, power, and the darker side of modernity. Wagadu: A Journal of Transnational Women's \& Gender Studies, 13, 108134. Recuperado de http://webhost1.cortland.edu/wp-content/uploads/2015/07/5-FIVEVeronelli.pdf

Walsh, C. (2007). Interculturalidad, colonialidad y educación. Revista Educación y Pedagogía. 19 (48) 25-35. Recuperado de http://www.flacsoandes.edu.ec/sites/default/files/agora/ files/1265909654.interculturalidad colonialidad y educacion 0.pdf 